\title{
Posttranscriptional Regulation of $\alpha$-Casein mRNA Accumulation by Laminin
}

\author{
MARY E. ZEIGLER ${ }^{1}$ AND MAX S. WICHA \\ Department of Internal Medicine, Division of Hematology and Oncology, Simpson Memorial Research Institute, \\ University of Michigan, 102 Observatory, Ann Arbor, Michigan 48109
}

\begin{abstract}
We have utilized primary cultures of rat mammary epithelial cells to study mechanisms by which laminin regulates the prolactin-dependent accumulation of $\alpha$ casein mRNA. Mammary cells accumulate approximately fivefold more $\alpha$-casein mRNA when cultured on laminin than when cultured on tissue plastic and the accumulation of $\alpha$-casein mRNA is prolactin dependent. On the basis of transcription assays there is approximately a twofold increase in the $\alpha$-casein mRNA transcription rate in cells cultured on laminin over that of tissue culture plastic. Measurements on the turnover of $\alpha$-casein mRNA show that this mRNA is stabilized fourfold more on laminin than on tissue culture plastic, while there was no significant difference in the turnover of poly(A) RNA on either substratum. These data indicate that laminin regulates the cytoplasmic levels of $\alpha$-casein mRNA accumulation primarily at the posttranscriptional level by increasing the stabilization of this mRNA. (1992 Academic Press, Inc.
\end{abstract}

\section{INTRODUCTION}

The development of the mammary gland into a specialized tissue capable of synthesis and secretion of milk proteins represents a complex interaction of pathways that both induce and maintain the differentiated phenotype. There is now considerable evidence that mammary cell differentiation is dependent upon steroid and peptide hormones, the extracellular matrix (ECM), ${ }^{2}$ and the organization of the cytoskeleton.

In vivo, mammary epithelial cells associate directly with a basement membrane, which in turn rests upon a stromal matrix of interstitial collagen (types I and III). Major constituents of the basement membrane include laminin, type IV collagen, sulfated proteoglycans, and entactin [1,2]. Mammary epithelial cells also demonstrate structural organization of the cytoskeleton

\footnotetext{
${ }^{1}$ To whom reprint requests and correspondence should be addressed.

${ }^{2}$ Abbreviations: ECM, extracellular matrix; TCP, tissue culture plastic; LMN, laminin; NC, nitrocellulose.
}

which, if disrupted, modifies milk protein gene expression [3]. In order to understand how the ECM functions in the presence of lactogenic hormones to regulate mammary cell differentiation, hormone- and ECM-responsive cell culture systems in serum-free media which permit the study of these pathways and their mechanisms of regulation have been developed [4-9]. Studies using primary murine mammary cell cultures have shown that stromal collagen and basement membrane components regulate the accumulation of casein mRNA and protein in a manner dependent upon the presence of prolactin, hydrocortisone, and insulin $[3,10,11]$.

Earlier studies, using rat mammary organ explant cultures, showed that casein mRNA accumulation requires the presence of prolactin to selectively regulate casein gene expression at the transcriptional and posttranscriptional levels [12]. Using primary mammary epithelial cell culture systems it is now possible to investigate the mechanisms by which the ECM and in particular individual components of the basement membrane regulate prolactin-dependent accumulation of casein mRNA. While substantial evidence demonstrates the positive effects of stromal collagen on mammary cell differentiation, studies have also suggested that this effect may be indirect and due to collagen-stimulated deposition of basement membrane components by mammary epithelial cells [50-54]. In view of these findings our studies have been directed toward understanding the mechanisms by which the basement membrane and in particular laminin, a major noncollagenous glycoprotein of the basement membrane, regulate milk protein gene expression $[3,10]$.

In this study we have investigated the mechanisms by which laminin induces and maintains prolactin-dependent accumulation of $\alpha$-casein mRNA in rat mammary epithelial cells. We present evidence that laminin regulates $\alpha$-casein mRNA accumulation primarily by stabilization of this mRNA.

\section{MATERIALS AND METHODS}

Cell cultures. Primary cultures of rat mammary epithelium were prepared from perphenazine-stimulated virgin female Sprague-Daw- 
ley rats and cultured on either laminin (LMN) or tissue culture plastic (TCP) at a density of $1.2 \times 10^{6}$ cells $/ 35-\mathrm{mm}$ dish. Laminin was isolated from EHS tumor extracts according to the method of Timpl et al. [55] and its purity assessed by SDS-PAGE and silver staining. Culture dishes were coated with laminin in PBS at $5 \mu \mathrm{g} / \mathrm{cm}^{2}$, allowed to dry overnight, and then rinsed in culture medium prior to plating mammary cells. Cells were plated initially in the presence of $5 \%$ fetal bovine serum and peptide and steroid hormones for $24 \mathrm{~h}$ and then subsequently cultured under serum-free conditions in the presence of these same hormones $(0.3 \mu \mathrm{g} / \mathrm{ml}$ prolactin, $5 \mu \mathrm{g} / \mathrm{ml}$ insulin, and 72 $\mathrm{ng} / \mathrm{ml}$ hydrocortisone) as previously described [10]. For prolactin induction and pulse-chase experiments cells were cultured as follows. After 4 days in serum-free prolactin-containing medium, mammary cells plated on TCP or LMN were cultured for $48 \mathrm{~h}$ in prolactin-free media. Prolactin was added to these cell cultures and induction of $\alpha$-casein mRNA measured over $72 \mathrm{~h}$ by Northern hybridization. The effect of prolactin withdrawal on $\alpha$-casein mRNA levels was measured by Northern hybridization. Cells were cultured for 4 days in serum-free media containing prolactin on LMN or TCP. Prolactin was then withdrawn from half of the cells cultured on either substratum and total cytoplasmic RNA was isolated $80 \mathrm{~h}$ later, bound to NC filters, and hybridized with a ${ }^{32} \mathrm{P}$-labeled $\alpha$-casein-specific cDNA fragment as described below. Pulse-chase procedures were performed as follows. After 4 days in prolactin-containing medium mammary cells were cultured for $48 \mathrm{~h}$ in prolactin-free medium followed by induction in prolactin-containing media for $24 \mathrm{~h}$. Mammary cells were then pulsed for $1.5 \mathrm{~h}$ with $120 \mu \mathrm{Ci} / \mathrm{ml}$ of $\left[{ }^{3} \mathrm{H}\right]$ uridine and subsequently chased for $24 \mathrm{~h}$ in the presence of $2 \mathrm{mM}$ cytidine and uridine.

Isolation and detection of unlabeled and ${ }^{3} H$-labeled $\alpha$-casein $m R N A$. Total cytoplasmic RNA was isolated from 7-day primary rat mammary cell cultures by detergent lysis in $1 \% \mathrm{NP}-40$ as described [10]. Total RNA was isolated from 10-day lactating rat mammary glands using the guanidinium isothiocyanate/CsCl method [13]. Northern blots were performed on $1.4 \%$ formaldehyde agarose gels as described by Maniatis et al. [14] and $\alpha$-casein mRNA was detected by hybridization to a $1.0 \cdot \mathrm{kb} \alpha$-casein-specific cDNA restriction fragment excised from a previously described $\mathrm{pBr} 322$ plasmid cDNA clone generously provided by J. M. Rosen [15] and then isolated by gel electrophoresis and electroelution. Glyceraldehyde 3-phosphate dehydrogenase (GAPDH) mRNA was detected using a ${ }^{32} \mathrm{P}$-labeled $1.0-\mathrm{kb}$ GAPDH-specific cDNA fragment isolated from plasmid pGAD 28 [16]. $\beta$-Actin (ACT) mRNA was detected using a ${ }^{32} \mathrm{P}$-labeled $1.2-\mathrm{kb}$ $\beta$-actin cDNA fragment isolated from pHF 5 [17]. Human histocompatibility antigen (HLA-B7) was detected using a ${ }^{32} \mathrm{P}$-labeled $1.4-\mathrm{kb}$ HLA-B-specific cDNA fragment isolated from pHLA-B7 [18]. These cDNA fragments were labeled by nick translation with ${ }^{32} \mathrm{P}$ to a specific activity of approximately $3-5 \times 10^{8} \mathrm{cpm} / \mu \mathrm{g}$. The amount of $\alpha$-casein was quantified by scintillation counting of $\mathrm{NC}$ filters as described below. ${ }^{3} \mathrm{H}$-labeled total cytoplasmic RNA was isolated as described [10] and ${ }^{3} \mathrm{H}$-labeled $\alpha$-casein mRNA was detected by hybridization under conditions of cDNA excess to $1 \mu \mathrm{g}$ of denatured $\mathrm{NC}$ filterbound $\alpha$-casein-specific cDNA fragment $(1.0 \mathrm{~kb})$ according to the methods previously described [19]. Prehybridization and hybridization were performed in $50 \%$ formamide, $5 \times$ SSPE, $2 \times$ Denhardt's, 1 $\mathrm{m} M$ EDTA, $0.1 \%$ SDS, $0.1 \mu \mathrm{g} / \mathrm{ml}$ SS DNA, $0.1 \mu \mathrm{g} / \mathrm{ml} \mathrm{tRNA}$, and 0.05 $\mu \mathrm{g} / \mathrm{ml}$ poly(A) RNA at $45^{\circ} \mathrm{C}$. Following hybridization filters were washed extensively in $0.1 \%$ SDS, and $2 \times$ SSPE at $45^{\circ} \mathrm{C}$ and then treated with RNAase A and RNAase T1 for $1 \mathrm{~h}$, rinsed extensively, and quantitated by scintillation counting in ACS (Amersham) subsequent to treatment with tetrahydrofuran to solubilize NC filters [20]. Background cpm bound to pBr322 DNA was subtracted before the cpm specifically bound to $\alpha$-casein cDNA was quantitated and was 10 to $18 \%$ of total cpm bound.

Isolation and detection of ${ }^{3} \mathrm{H}$-labeled poly(A) RNA and $r R N A$. At 0 $\mathrm{h}$ and at indicated times during the chase, ${ }^{3} \mathrm{H}$-labeled poly(A) RNA was purified from ${ }^{3} \mathrm{H}$-labeled total cytoplasmic RNA by twice batch binding and eluting on oligo(dT)-cellulose (Collaborative Research) as previously reported [21]. ${ }^{3} \mathrm{H}$-labeled poly(A) RNA was measured by counting the eluate in ACS (Amersham). At $3 \mathrm{~h}$ following labeled pool equilibration, ${ }^{3} \mathrm{H}$-labeled poly(A) RNA represented $2-6 \%$ of ${ }^{3} \mathrm{H}$ labeled 28-S rRNA. ${ }^{3} \mathrm{H}$-labeled rRNA was measured as follows. After precipitation in $0.3 \mathrm{M}$ sodium acetate, ${ }^{3} \mathrm{H}$-labeled total cytoplasmic RNA was fractionated on nondenaturing $0.7 \%$ agarose gels and ${ }^{3} \mathrm{H}$ labeled rRNA was measured directly by excising the 28-S rRNA bands visualized by ethidium bromide staining, dissolving the agarose in NCS (Amersham) at $50^{\circ} \mathrm{C}$ for $1 \mathrm{~h}$ and counting in OCS (Amersham).

Calculations of $\alpha$-casein $m R N A$, cytoplasmic poly $(A) R N A$, and 28-S $r R N A$ turnover. The prolactin induction profile of $\alpha$-casein $\mathrm{mRNA}$ depicted in Fig. 2A was obtained by calculating the cpm of $\alpha$-casein $\mathrm{mRNA} / \mu \mathrm{g}$ of total cytoplasmic RNA ( $y$-axis) obtained from Northern blot analysis and plotting these values as a function of time after prolactin addition ( $x$-axis) and the curve of best fit derived by regression analysis. As previously described $[22,23]$ hormone-induced accumulation of mRNA may be represented by the equation

$$
C_{t}=T / D-\left(T / D-C_{0}\right) e^{-D t},
$$

in which $C_{t}$ is the concentration of mRNA at time $t, C_{0}$ is the initial concentration of mRNA, $T$ is the transcription rate, and $D$ is the mRNA degradation rate constant. The accumulation curves depicted in Fig. 2A closely approximates the curve described by Eq. (1). The derivative of Eq. (1) is given by the equation

$$
d C / d t=T-D C_{t}
$$

Estimates of half-life and transcription rate were derived as previously described $[12,24,29]$ based upon obtaining values for parameters described in Eq. (2). The methodology used is described as follows. Based on Fig. 2A the slope of the curve between adjacent time intervals, $\Delta C / \Delta t$, was used to approximate the value $d C / d t$, i.e., the rate of change in the concentration of $\alpha$-casein mRNA/ $\mu \mathrm{g}$ of total cytoplasmic RNA as previously described $[17,40]$. These values were plotted as a function of $C_{t}$, the concentration of $\alpha$-casein $\mathrm{mRNA} / \mu \mathrm{g}$ total cytoplasmic RNA, i.e., the mid- $C$ value over this same time interval. The curves in Fig. 6 were obtained by linear regression analysis and, judging by the fit of the curve to the data, can be represented by the equation $d C / d t=T-D C_{t}$. Thus the rate of change in the concentration of $\alpha$-casein mRNA is represented by $d C / d t$, where $C_{t}$ is the concentration of $\alpha$-casein mRNA at any given time, $t$, and the slope of these curves is given by $D$, the degradation rate constant, and is used to calculate the $t_{1 / 2}$ by the expression $\ln 2=D t_{1 / 2}$ as previously described [23]. The transcription rate, $T$, is estimated by extrapolation to the $y$-axis.

The turnover of $\alpha$-casein mRNA by pulse-chain analysis was determined by measuring the cpm specifically hybridized to filterbound $\alpha$-casein cDNA and dividing by the mass of total cytoplasmic RNA applied to the filter at $0 \mathrm{~h}$ and at $3,6,12,18$, and $24 \mathrm{~h}$ during the chase. The cpm specifically bound to $\alpha$-casein mRNA was measured after subtraction of background $\mathrm{cpm}$ hybridized to filter-bound pBR322 and was approximately 10 to $18 \%$ of total cpm bound. Measurement of ${ }^{3} \mathrm{H}$-labeled cytoplasmic poly(A) RNA turnover was performed by determining the cpm specifically bound and subsequently eluted from oligo(dT)-cellulose relative to the mass of total cytoplasmic RNA applied to the oligo(dT)-cellulose. ${ }^{3} \mathrm{H}$-labeled $28-\mathrm{S}$ rRNA turnover was quantified as described above. The cpm in the $28-\mathrm{S}$ rRNA band was measured by scintillation counting and then this value was divided by the mass of total cytoplasmic RNA applied to the agarose gel.

Actinomycin D treatment of rat mammary cell cultures. Rat mammary cells cultured on either LMN or TCP as described for pulsechase assays were treated with actinomycin $\mathrm{D}(5 \mu \mathrm{g} / \mathrm{ml})$ at Day 7 in culture. Total cytoplasmic RNA was isolated at Time $0,1,3$, and $5 \mathrm{~h}$ 
following the addition of actinomycin D as described above. $\alpha$-Casein mRNA was detected by Northern blot analysis and quantified by scintillation counting of NC filters.

Run-on transcription assays. Rat mammary cells were cultured on either LMN or TCP substratum as described for the prolactin induction assay and pulse-chase experiments. Nuclei were isolated from these cells $24 \mathrm{~h}$ after prolactin induction during the time when linear accumulation of $\alpha$-casein mRNA occurs (Fig. 2). Procedures for isolation and labeling of nuclei were performed essentially as described [62]. Briefly, nuclei $\left(30-40 \times 10^{6}\right)$ were incubated in the presence of $500 \mu \mathrm{Ci}$ of $\left.{ }^{32} \mathrm{P}\right] \mathrm{UTP}(3000 \mathrm{Ci} / \mathrm{mmol})$. Equal amounts of ${ }^{32} \mathrm{P}$-labeled RNA $\left(6 \times 10^{6} \mathrm{cpm} / \mathrm{ml}\right.$ in a volume of $\left.2 \mathrm{ml}\right)$ isolated from cells cultured on either LMN or TCP were hybridized to $800 \mathrm{ng}$ denatured, filterbound $\alpha$-casein-specific cDNA as described elsewhere [25]. In some cases, nuclei isolated from these cells cultured on LMN substratum were incubated with $2.5 \mu \mathrm{g} / \mathrm{ml}$ of $\alpha$-amanitin in the presence of $\left[{ }^{32} \mathrm{P}\right]$ UTP and equal amounts of ${ }^{32}$ P-labeled RNA $\left(2 \times 10^{6} \mathrm{cpm} / \mathrm{ml}\right.$ in a volume of $2 \mathrm{ml}$ ) were hybridized to filter-bound $\alpha$-casein cDNA as described above. $\alpha$-Casein transcripts specifically bound to $\alpha$-casein cDNA were detected by autoradiography and quantified by liquid scintillation counting. Transcription rate was expressed as cpm bound to $\alpha$-casein cDNA - cpm bound to $\mathrm{pBr} 322 \times[1 \div$ input cpm in $\left.\left(10^{6} \mathrm{cpm}\right)\right] \times[1 \div$ insert in $(\mathrm{kb})]=\mathrm{ppm} / \mathrm{kb}$. The actin-specific transcription rate was measured by the same method.

\section{RESULTS}

To determine the mechanisms by which laminin regulates $\alpha$-casein gene expression we first measured by Northern blot analysis the steady-state accumulation of $\alpha$-casein mRNA in primary rat mammary cells cultured on LMN or TCP in the presence of lactogenic hormones. As shown in Fig. 1 nearly fivefold more $\alpha$-casein mRNA accumulates in cells cultured on LMN than on cells cultured on TCP. In order to ascertain the effect of laminin on the accumulation of nonmilk protein genes we also measured mRNA levels of GAPDH, ACT, and HLA-B7. As shown in Fig. 1 the steady-state levels of these mRNAs are regulated differently by laminin, in which virtually no difference is seen in the levels of HLA-B7 mRNA on either substratum. In contrast there is a measurable decrease in mRNA levels of GAPDH and a lesser decrease in the mRNA levels of actin on LMN from those in TCP, indicating that there is a range of substratum responsiveness of individual nonmilk protein mRNAs in the total cytoplasmic pool of mRNAs in mammary epithelial cells. Recent studies have also demonstrated that a complex basement membrane substrata differentially regulates tissue-specific hepatic gene expression and cytoskeletal gene expression in which cytoskeletal mRNA levels are inversely regulated relative to tissue-specific hepatic gene expression [61].

It has been shown that mammary cell differentiation is marked by prolactin-dependent induction of casein synthesis [12, 26-28]. To demonstrate that our cell culture system could serve as a model of this hormonal response and to ascertain the effect of laminin substratum on prolactin-induced $\alpha$-casein gene expression, we

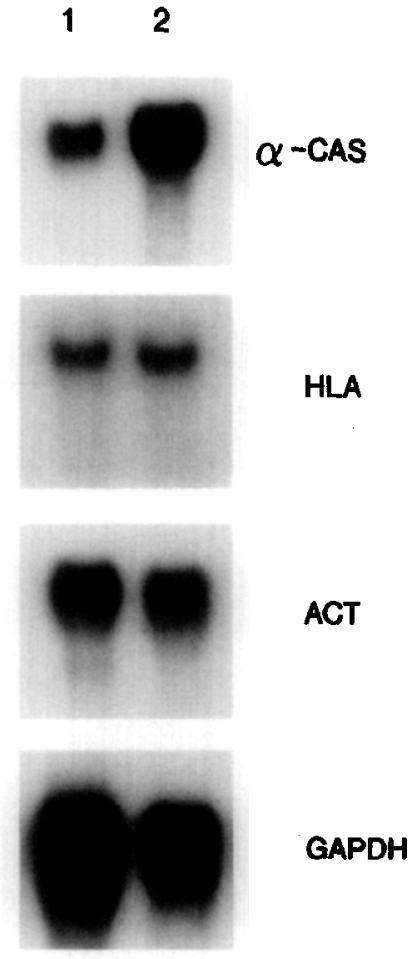

FIG. 1. Steady-state accumulation of $\alpha$-casein mRNA in cells cultured on LMN substrata and TCP. Total cytoplasmic RNA was isolated from cell cultured on either LMN or TCP. Equal amounts of RNA were size fractionated on denaturing agarose gel. Lanes 1 , TCP $(20 \mu \mathrm{g})$ and $2, \mathrm{LMN}(20 \mu \mathrm{g}) \cdot \alpha$-Casein $(\alpha$-CAS), HLA-B7 (HLA), actin (ACT), and glyceraldehyde 3-phosphate dehydrogenase (GAPDH) mRNA were detected by Northern hybridization using ${ }^{32} \mathrm{P}$-labeled $\alpha$-casein-, HLA-, ACT-, and GAPDH-specific cDNA fragments as indicated and variously exposed to autoradiographic film for $1.5,24$, 2 , and $24 \mathrm{~h}$, respectively. The relative amount of $\alpha$-casein accumulated on TCP and LMN substrata was calculated as a percentage of lactating RNA (not shown) and the ratio of $\alpha$-casein mRNA for LMN vs TCP is $4.7 \pm 1.5 \mathrm{SD}$ for four experiments.

measured the accumulation of $\alpha$-casein mRNA on LMN or TCP following prolactin addition. Over a period of 48 $\mathrm{h} \alpha$-casein mRNA accumulates more rapidly on LMN than on TCP (Fig. 2A) whereas accumulation of 28-S rRNA as measured by ethidium bromide staining or hybridization to 28-S rRNA cDNA remained unchanged after prolactin addition (data not shown). However, when prolactin is withdrawn from cells previously cultured on either substratum for 4 days in the presence of prolactin, $\alpha$-casein mRNA levels decrease after $80 \mathrm{~h}$ to a level approximately $30 \%$ of the level in cells cultured on these substrata in the presence of prolactin (Fig. 2B). These results would suggest that the while laminin has a potentiating effect on $\alpha$-casein mRNA accumulation, this effect is clearly prolactin dependent.

The increase in the steady-state accumulation of cytoplasmic pools of $\alpha$-casein mRNA on LMN vs TCP might be accounted for by an increase in transcription rate and/or stabilization of $\alpha$-casein mRNA. To mea- 
A

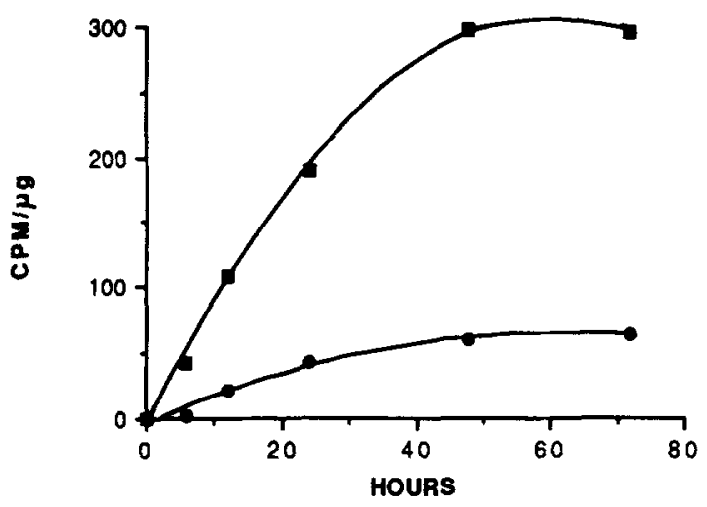

B

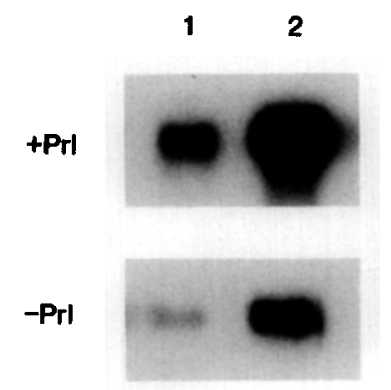

FIG. 2. Prolactin induction and deinduction of $\alpha$-casein mRNA in cells cultured on LMN and TCP. Northern hybridization was performed on total cytoplasmic RNA isolated from cells cultured on either LMN or TCP and quantified as described under Materials and Methods. (A) Induction profile of $\alpha$-casein mRNA on LMN (ש) and TCP (O) is depicted with the values on the $y$-axis designated as cpm of $\alpha$-casein mRNA/ $\mu \mathrm{g}$ of total cytoplasmic RNA and values on the $x$-axis designated as indications of times after prolactin addition. (B) Northern hybridization using ${ }^{32} \mathrm{P}$-labcled $\alpha$-casein-specific cDNA probe was performed on total cytoplasmic RNA isolated from cells cultured on TCP (lane 1) or LMN (lane 2) in the presence or absence of prolactin as shown. The level of $\alpha$-casein mRNA was measured by densitometry scans.

sure the effects of laminin on transcription rate we performed run-on transcription assays using equal numbers of nuclei isolated from cells cultured on LMN or TCP under the same conditions as those described for pulse-chase analysis. Nuclei were isolated from cells cultured on either substratum $24 \mathrm{~h}$ after prolactin induction during the period of linear accumulation of cytoplasmic $\alpha$-casein mRNA. A sample dot blot is depicted in Fig. 3. As indicated in Table 2 there is an approximately 1.5 -fold increase in $\alpha$-casein transcription rate on LMN over that of TCP. The transcription rate of cytoplasmic actin was also measured and virtually no difference is seen in the in transcript levels on either substratum although there is approximately 3-fold more actin specific transcripts than $\alpha$-casein specific transcripts. Nearly $90 \%$ of $\alpha$-casein transcription was inhibited by $2.5 \mu \mathrm{g} / \mathrm{ml}$ of $\alpha$-amanitin, showing that transcription was specific for RNA polymerase II activity. The data summarized in Table $2 \mathrm{~A}$ indicate that the 1.5-

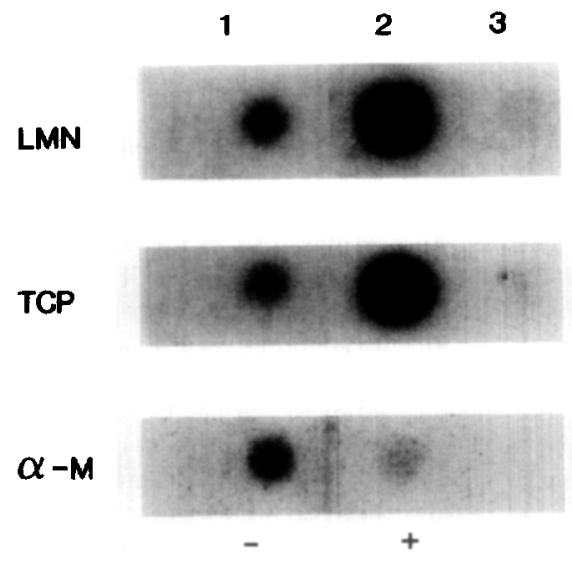

FIG. 3. In vitro transcription assay of $\alpha$-casein mRNA. Equivalent amounts of ${ }^{32} \mathrm{P}$-labeled RNA isolated from cells cultured on LMN or TCP were hybridized to denatured filter-bound $\alpha$-caseinspecific and actin-specific cDNA fragment as well as $\mathrm{pBr} 322$-specific DNA, LMN, and TCP: Lanes $1, \alpha$-casein; 2 , actin, and 3, pBr322. Nuclei isolated from cells cultured on LMN were also incubated in the presence or absence of $2.5 \mu \mathrm{g} / \mathrm{ml}$ of $\alpha$-amanitin and equal amounts of ${ }^{32} \mathrm{P}$-labeled RNA isolated from cells cultured under these conditions were hybridized to filter-bound $\alpha$-casein cDNA as described above. $\alpha$-M: lane $1,(-) \alpha$-amanitin, Lane $2,(+) \alpha$-amanitin. The relative amount of ${ }^{32} \mathrm{P}$-labeled RNA specifically bound to $\alpha$-casein $\mathrm{cDNA}$ was quantified by scintillation counting.

fold increase in transcription rate can account for only $25-30 \%$ of the fold increase in $\alpha$-casein mRNA accumulation on LMN over that on TCP. On the basis of these results we proceeded to measure the effect of $\mathrm{mRNA}$ stabilization on the accumulation of $\alpha$-casein mRNA.

Measurements of mRNA half-life may be obtained either by inhibiting transcription and assaying the decay of unlabeled mRNA or by pulse-chase assays which follow the decay of ${ }^{3} \mathrm{H}$-labeled mRNA. When we used actinomycin $\mathrm{D}$ to inhibit transcription and assayed for the decay of unlabeled $\alpha$-casein mRNA cytoplasmic pools we found virtually no detectable change in the level of $\alpha$-casein mRNA during $5 \mathrm{~h}$ following the addition of actinomycin D (Fig. 4). These data suggested that the half-life of $\alpha$-casein mRNA in cells cultured on LMN or TCP was longer than $5 \mathrm{~h}$. However, measurement of $\alpha$-casein mRNA turnover in the presence of

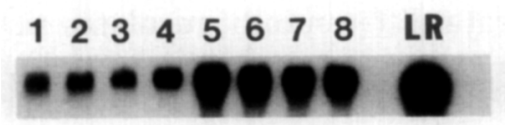

FIG. 4. Affect of actinomycin D on $\alpha$-casein mRNA degradation. Rat mammary cells cultured on LMN and TCP were treated with actinomycin $\mathrm{D}(5 \mu \mathrm{g} / \mathrm{ml})$ and at $0,1,3$, and $5 \mathrm{~h}$ total cytoplasmic RNA was isolated from these cells and then hybridized by Northern blot with ${ }^{32} \mathrm{P}$-labeled $\alpha$-casein cDNA. Lanes 1-4, RNA isolated from cells cultured on TCP at $0,1,3$, and $5 \mathrm{~h}$, respectively. Lanes $5-8$, RNA isolated from cells cultured on LMN at $0,1,3$, and $5 \mathrm{~h}$, respectively. 'Twenty micrograms of total cytoplasmic RNA was applied to each lane. LR, $3 \mu \mathrm{g}$ total RNA from lactating rat mammary gland. 
TABLE 1

Turnover of ${ }^{3} \mathrm{H}$-Labeled RNA Species in Rat Mammary Cells

\begin{tabular}{|c|c|c|c|c|c|c|}
\hline Duration of chase hours & TCP & LMN & TCP & LMN & TCP & LMN \\
\hline 0 & $0.43 \pm 0.10$ & $0.74 \pm 0.12$ & $1.10 \pm 0.32$ & $1.77 \pm 0.36$ & $0.82 \pm 0.14$ & $1.04 \pm 0.22$ \\
\hline 3 & $2.30 \pm 0.23$ & $3.15 \pm 0.50$ & $2.08 \pm 0.31(100)$ & $3.54 \pm 0.50(100)$ & $1.52 \pm 0.05(100)$ & $1.56 \pm 0.12(100)$ \\
\hline 6 & $2.46 \pm 0.40$ & $3.32 \pm 0.15$ & $1.45 \pm 0.16(70)$ & $3.30 \pm 0.17(93)$ & $1.13 \pm 0.03(74)$ & $1.20 \pm 0.06(77)$ \\
\hline 24 & $2.35 \pm 0.41$ & $3.37 \pm 0.20$ & $0.64 \pm 0.14$ & $2.37 \pm 0.18(67)$ & $0.44 \pm 0.03(29)$ & $0.62 \pm 0.01$ \\
\hline
\end{tabular}

Note. The turnover of ${ }^{3} \mathrm{H}$-labeled RNA species is expressed as the total cpm specifically incorporated into 28-S rRNA, $\alpha$-casein mRNA, and poly(A) RNA divided by the input mass of total cytoplasmic RNA. The input mass of RNA per time point on either TCP or LMN ranged between 60 and $90 \mu \mathrm{g}$. All values except the 18-h time point are reported $\pm \mathrm{SE}$ and represent the results of two or three experiments. Values in parentheses represent the percentage mRNA relative to $T_{0}$ taken as the value at $3 \mathrm{~h}$.

actinomycin $\mathrm{D}$ beyond $5 \mathrm{~h}$ was precluded due to changes in cell morphology and cell detachment from the substrata.

To measure more directly the half-life of $\alpha$-casein mRNA we performed pulse-chase analysis in which ${ }^{3} \mathrm{H}$ labeled $\alpha$-casein mRNA was measured by hybridization to filter-bound $\alpha$-casein cDNA. As noted in Table 1 appreciable accumulation of label in ribosomal RNA continued over the first $3 \mathrm{~h}$ of the chase, indicating that depletion of the radioactive precursor pool did not occur until after this interval. This profile of incorporation was also evident in $\alpha$-casein mRNA and poly(A) RNA. As the data indicate, an effective chase begins $3 \mathrm{~h}$ after transfer to the chase media and therefore the incorporation of label into RNA at $3 \mathrm{~h}$ is taken as $T_{0}$. The turnover of cytoplasmic $\alpha$-casein mRNA and poly(A) RNA is calculated by measuring the amount of ${ }^{3} \mathrm{H}$ label incorporated into these species per microgram of total cytoplasmic RNA and then normalizing to the value of $T_{0}$ at $3 \mathrm{~h}$ (Table 1). The exponential decay curve of $\alpha$-casein mRNA derived from these data is shown in Fig. 5A. The half-life of $\alpha$-casein mRNA obtained by this method is approximately $41 \mathrm{~h}$ in cells cultured on LMN and $10 \mathrm{~h}$ in cells cultured on TCP. These results indicate that $\alpha$-casein mRNA is stabilized approximately fourfold more on LMN than on TCP. Given these data, approximately $80 \%$ of the nearly fivefold increase in accumulation of cytoplasmic pools of $\alpha$-casein mRNA on laminin could be accounted for by stabilization of this mRNA.

As previously demonstrated in Fig. 1 laminin substratum variably affects the accumulation of $\mathrm{mRNA}$ of several nonmilk protein genes. These results suggested that no specific mRNA species could serve as a representative of total cytoplasmic poly(A) RNA pools in order to assess the change in $\alpha$-casein stabilization relative to this total pool. For this reason we measured the turnover of total cytoplasmic poly(A) RNA by pulse-chase analysis. The results depicted in Fig. 5B show that on
LMN substratum as compared to TCP the half-life of poly(A) RNA is $17 \mathrm{~h}$ and $14 \mathrm{~h}$, respectively. This small difference in turnover of the total cytoplasmic poly(A) levels may reflect in part differences in $\alpha$-casein mRNA turnover since this mRNA may constitute an appreciable portion of the total cytoplasmic mRNA pool in cells cultured on laminin, which is positively modulated by this substratum. This minimal difference in total poly(A) turnover on either substratum suggests that laminin exerts a more selective effect on the stabilization of $\alpha$-casein mRNA than on that of total cytoplasmic mRNA.

\section{DISCUSSION}

The use of mammary cell culture systems has made it possible to investigate the mechanisms by which steroid and peptide hormones and the ECM function in the induction of mammary cell differentiation as measured by the regulated expression of milk protein genes. Studies, including our own, have demonstrated that in the presence of lactogenic hormones the accumulation of casein mRNA and protein is increased in mammary cells cultured on basement membrane substrata over that of cells cultured on tissue culture plastic $[3,10,11]$.

Given the inherent difficulties in using complex basement membrane gel matrices to measure mechanisms regulating rates of synthesis and turnover of casein mRNA and proteins, we chose to investigate the effect of laminin, a principal component of the basement membrane, on the regulation of $\alpha$-casein mRNA accumulation. Recent studies have shown that laminin regulates several cellular processes including growth [30, $31]$, adhesion [32,33], and migration [34]. Furthermore, it has been demonstrated that laminin can promote cellular differentiation involving the formation of endothelial cells into capillary-like structures [35] and the induction of myogenesis in skeletal muscle cell cultures 
A

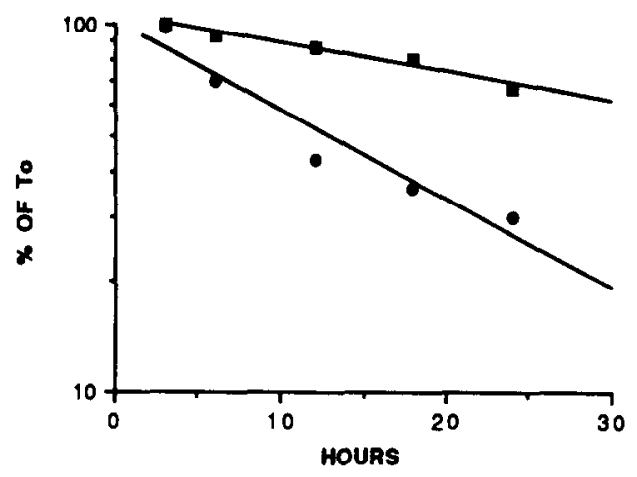

B

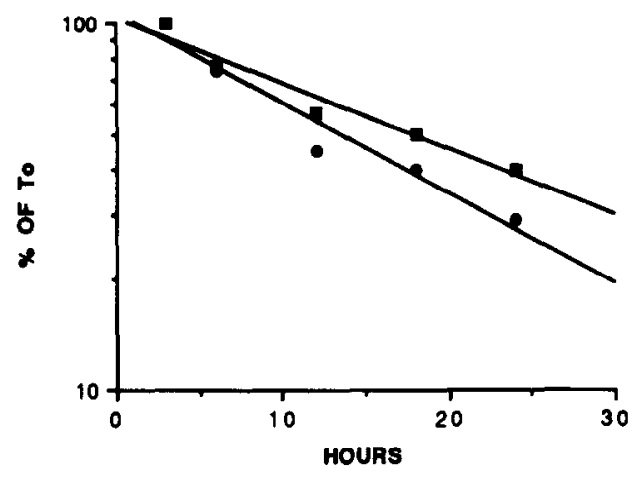

FIG. 5. Turnover of $\alpha$-casein mRNA and poly(A) RNA. (A) Turnover of $\alpha$-casein mRNA was measured by pulse-chase experiments of ${ }^{3} \mathrm{H}$-labeled cytoplasmic RNA isolated after a 1.5 -h pulse in $\left[{ }^{3} \mathrm{H}\right]$ uridine designated $0 \mathrm{~h}$ and at $3,6,12,18$, and $24 \mathrm{~h}$ following the chase in $2 \mathrm{~m} M$ uridine and cytidine. Values for each time point are given as cpm specifically hybridized to filter-bound $\alpha$-casein $\mathrm{cDNA} / \mu \mathrm{g}$ total cytoplasmic RNA and subsequently expressed as a percentage of the value at $3 \mathrm{~h}$, which is designated as $T_{0}$ (see Table 1). Except for the 18-h time point all other time points represent the mean values of two or three experiments: LMN ( $\boldsymbol{D}$ ) and TCP (•). (B) Turnover of poly(A) RNA was measured by pulse-chase experiments as described in (A). ${ }^{3} \mathrm{H}$-labeled poly(A) RNA was isolated as described under Materials and Methods from ${ }^{3} \mathrm{H}$-labeled total cytoplasmic RNA at $0 \mathrm{~h}$ and at $3,6,12,18$, and $24 \mathrm{~h}$ following the chase. Values for each time point represent $\mathrm{cpm}$ specifically bound and eluted from oligo(dT)-cellulose per microgram of total cytoplasmic RNA and subsequently expressed as a percentage of the value at $3 \mathrm{~h}$ designated as $T_{0}$. The values at each time point represent the mean of two experiments: LMN ( $(\mathbf{)})$ and TCP (•).

[36]. In our recent studies we have demonstrated that laminin used as a substratum in the culture of rat primary epithelial cells can regulate mammary cell differentiation as measured by the accumulation of $\alpha$-casein mRNA and protein in the presence of lactogenic hormones $[3,10]$. However, the mechanisms by which laminin substratum regulates the levels of $\alpha$-casein mRNA have not been defined.

In this study we have attempted to assess the role of transcriptional and posttranscriptional control in the regulation of prolactin-dependent cytoplasmic accumulation of $\alpha$-casein mRNA. We used primary rat mam- mary cells cultured on laminin or tissue culture substrata in hormonally defined, serum-free media containing insulin, hydrocortisone, and prolactin. Under these conditions cell growth is negligible and thus not a factor in the measurements determining differences in accumulation or turnover of $\alpha$-casein mRNA in cells cultured on laminin or tissue culture plastic.

A number of studies have demonstrated the essential role of prolactin in regulating the synthesis of $\alpha$-casein mRNA and protein $[12,26-28]$. For this reason we measured the inductive effect of prolactin in the presence of insulin and hydrocortisone on $\alpha$-casein mRNA accumulation and demonstrated that the cell culture system is hormonally responsive, meeting an essential criterion as a model system for the study of mammary cell differentiation.

The induction assay showed that laminin can potentiate the inductive effect of prolactin, resulting in an accumulation of cytoplasmic $\alpha$-casein mRNA on laminin nearly fivefold greater than that on tissue culture plastic (Fig. 2A). However, when prolactin is withdrawn, $\alpha$-casein mRNA accumulation decreases even in the presence of laminin, suggesting that the effect of laminin on milk protein gene expression is essentially prolactin dependent (Fig. 2B).

The net accumulation of $\mathrm{mRNA}$ at any given time is a function of both its rate of synthesis and its rate of degradation. In the case of casein $\mathrm{mRNA}$ accumulation it was shown that prolactin regulated casein mRNA accumulation by increasing both its rate of synthesis and its stability. The fold accumulation, however, was shown to be due primarily to stabilization of casein mRNA [12, 26]. These studies were conducted using intact mammary gland or organ cultures and therefore precluded an investigation of the role of basement membrane substrata in prolactin-induced casein mRNA accumulation. We had previously demonstrated that laminin as well as complex basement membrane substrata could increase the steady-state levels of $\alpha$-casein mRNA but we did not define the mechanisms regulating this process. In this study we sought to measure the relative contribution of stabilization in the accumulation of $\mathrm{cy}$ toplasmic pools of $\alpha$-casein mRNA by laminin.

We have shown that the fold induction in the accumulation of $\alpha$-casein mRNA on laminin substratum is accounted for primarily by posttranscriptional stabilization of $\alpha$-casein mRNA cytoplasmic pools. Based on the pulse-chase assays which measured the turnover in the cytoplasmic mRNA pools, $\alpha$-casein mRNA decayed exponentially and followed first-order kinetics as judged by the fit of the data to the curve using regression analysis (Fig. 5A). However, since pulse-chase assays may lead to an overestimate of half-life due to the inability to effect rapid equilibration of labeled precursor pools we can also make use of an indirect approach based on the hormone-dependent accumulation of 


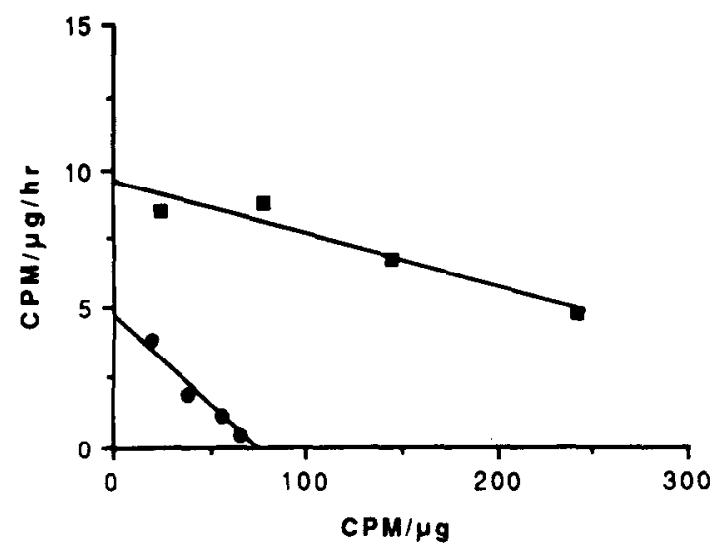

FIG. 6. Estimation of $\alpha$-casein mRNA half-life and transcription rates. The curves for LMN ( $(\square)$ and TCP $(\bullet)$ were derived as described under Materials and Methods. Estimates of half-life are obtained from the slope of the curve, $D$, using the equation $\ln 2 / D=t_{1 / 2}$. Estimates of transcription rates are obtained from the $y$-axis intercept, which denotes cpm of $\alpha$-casein mRNA/ $\mu \mathrm{g}$ of total cytoplasmic RNA/ h. Values on the $x$-axis denote $\mathrm{cpm}$ of $\alpha$-casein mRNA/ $\mu \mathrm{g}$ of total cytoplasmic RNA.

mRNA as previously described $[12,22,23,29]$ to obtain an estimate of the turnover and transcription rate of $\alpha$-casein mRNA in cells cultured in laminin and TCP. The equations used in these studies were based on assumptions that mRNA decay is exponential and follows first-order decay kinetics. Since the turnover of $\alpha$-casein mRNA meets these criteria as demonstrated by the pulse-chase assay, the hormone-dependent accumulation of $\alpha$-casein mRNA was judged a reasonable approach in obtaining estimates of half-life and transcription rate of this mRNA. The estimates of half-life and transcription rate of $\alpha$-casein mRNA in mammary cells cultured on LMN an TCP are obtained from the curves depicted in Fig. 6. The derivation of these curves is described under Materials and Methods and is based on the $\alpha$-casein mRNA accumulation curves shown in Fig. 2A. The curves shown in Fig. 6 indicate the rate of change in the accumulation of $\alpha$-casein mRNA $(d C / d t)$ as a function of the concentration of $\alpha$-casein mRNA $\left(C_{t}\right)$ at time $t$ and can be described by the equation $d C / d t$ $=T-D C_{t}$. The estimates of transcription rate, $T$, are obtained by the values at the $y$-axis intercept and are 4.4 and $9.5 \mathrm{cpm}$ of $\alpha$-casein mRNA/ $\mu \mathrm{g}$ of total cytoplasmic $\mathrm{RNA} / \mathrm{h}$ in cells cultured on TCP and LMN, respectively. The half-life of $\alpha$-casein mRNA is estimated from $D$, the slope of the curve which is related to $t_{1 / 2}$ (the half-life) by the expression $t_{1 / 2}=\ln 2 / D$ [23]. The estimates of half-life based on this equation are approximately 37 and $10 \mathrm{~h}$ in cells cultured on LMN and TCP, respectively. Thus while there is approximately a 2 -fold increase in transcription rate in cells cultured on LMN over that of cells cultured on TCP, there is a nearly 4 -fold increase in $\alpha$-casein mRNA half-life on laminin substratum. As indicated in Table 2B the estimates in the turnover and transcription rates of $\alpha$-casein mRNA on LMN versus TCP compare favorably with those values obtained by pulse-chase analysis. Since $\alpha$-casein mRNA accumulates nearly 5 -fold more on LMN than on TCP and $\alpha$-casein mRNA is stabilized 4.1-fold more in mammary cells cultured on LMN than in those cultured on TCP, stabilization of $\alpha$-casein mRNA by LMN accounts for $70-80 \%$ of the accumulation of this mRNA (Table 2). These data suggest that $\alpha$-casein mRNA levels are regulated primarily at the posttranscriptional level.

These findings are consistent with previous reports indicating that both hormonal and collagenous substratum regulation of $\beta$-casein mRNA accumulation in a murine mammary epithelial cell line could not be accounted for solely by the changes in the transcription rate of this mRNA. While $\beta$-casein mRNA stability was not measured in these studies it was concluded that posttranscriptional stabilization of $\beta$-casein mRNA was most probably the primary mechanism contributing to the steady-state accumulation of this mRNA [37, 38].

While these reports, including our own, clearly indicate the significant contribution of posttranscriptional mechanisms in regulating casein gene expression it is important to note that casein gene expression represents a complex interaction of both hormonal and substratum pathways involving both transcriptional and posttranscriptional mechanisms. Several studies have begun to identify DNA sequences involved in the hormonal- and substratum-dependent regulation of $\beta$-casein gene transcription using $\beta$-casein gene promoter constructs [56-59]. In a recent report lactogenic hor-

\section{TABLE 2}

Values for the Half-life and Transcription Rate of $\alpha$-Casein mRNA Based on Pulse-Chase Analysis, Run-on Transcription Assays, and Prolactin-Induced Accumulation Data

\begin{tabular}{cc}
\hline Half-life $(\mathrm{h})$ & Transcription rate $(\mathrm{ppm} / \mathrm{kb})$ \\
\hline
\end{tabular}

A. Pulse-chase and run-on transcription assay

$\begin{array}{lll}\text { LMN } & 41(4.1) & 22.5 \pm 1.5(1.5) \\ \text { TCP } & 10 & 15.3 \pm 0.5\end{array}$

B. Accumulation data

\begin{tabular}{lll} 
LMN & $37(3.7)$ & $9.5(2.2)$ \\
TCP & 10 & 4.4 \\
\hline
\end{tabular}

Note. (A) These values represent the turnover of $\alpha$-casein mRNA as measured by pulse-chase assays depicted in Fig. 4A. The transcription rate was measured by run-on assays performed with isolated nuclei as described under Materials and Methods. (B) These values represent the turnover of $\alpha$-casein mRNA derived from the accumulation data as depicted in Fig. 2B. The transcription rate derived from the accumulation data, Fig. 2B, represents the cpm of $\alpha$-casein $\mathrm{mRNA} / \mu \mathrm{g}$ of total cytoplasmic RNA/h. The values in parentheses denote the fold increase on LMN relative to TCP. 
mone-dependent nuclear factors and their binding sites in the $\beta$-casein gene promoter region have been identified [60].

We believe that our study provides a basis for identifying laminin-responsive elements in mammary epithelial cells which contribute to the hormonal dependent stabilization of $\alpha$-casein mRNA. These elements may compose a signal transduction mechanism linking the ECM, its cell surface receptors, and the cytoskeleton in optimizing the expression of hormonally regulated milk protein gene expression. Recent studies have demonstrated that maintenance of cytoplasmic levels of mRNA and subsequent protein synthesis are dependent upon whether these RNAs are associated with the cytoskeleton [39-42]. Other studies have shown that laminin interacts with a variety of cells via cell surface laminin binding proteins, some of which are functionally linked to the cytoskeleton [43-48]. It has been demonstrated that laminin binding to cell surface lamininbinding proteins induces both redistribution of these proteins in the plasma membrane and functional linkage to the cytoskeleton $[44,47]$. Recently other cell surface ECM receptors, including those belonging to the integrin family, which interact with the cytoskeleton have been described $[49,63]$. It remains to be determined whether similar receptor/cytoskeleton interactions are present in mammary epithelial cells and are utilized in similar signal transduction pathways for the regulation of milk protein gene expression. The use of primary mammary cell cultures responsive both to peptide and to steroid hormones and ECM components can serve as a model system to elucidate the molecular basis by which these pathways function in regulating the process of mammary cell differentiation.

We thank George Lowrie for excellent technical assistance. This work was supported by Grants GM-37091 from the NIH and BC-357 from the American Cancer Society.

\section{REFERENCES}

1. Kefalides, N. A., Alper, R., and Clark, C. (1979) Int. Rev. Cytol. 61, 167-228.

2. Kleinman, H. K., McGarvey, M. L., Hassell, J. R., Star, V. L., Cannon, F. B., Laurie, G. W., and Martin, G. R. (1986) Biochemistry 25, 312-318.

3. Blum, J. L., and Wicha, M. S. (1988) J. Cell Physiol. 135, 13-22.

4. Wicha, M. S., Lowrie, G., Kohn, E., Bagavandoss, P., and Mahn, T. (1982) Proc. Natl. Acad. Sci. USA 79, 3213-3217.

5. Rocha, V., Ringo, D. L., and Read, D. B. (1985) Exp. Cell Res. 159, 201-210.

6. Suard, U., Haeuptle, M., Farinon, E., and Krachenbuhl, J. (1983) J. Cell Biol. 96, 1435-1442.

7. Terry, P., Banerjee, M. R., and Lui, R. M. (1977) Proc. Natl. Acad. Sci. USA 74, 2441-2445.

8. Lee, E., Lee, W., Kaetzel, C. S., Parry, G., and Bissell, M. (1985) Proc. Natl. Acad. Sci. USA 82, 1419-1423.
9. Matusik, R. J., and Rosen, J. M. (1978) J. Biol. Chem. 253, 2343-2347.

10. Blum, J. L., Zeigler, M. E., and Wicha, M. S. (1987) Exp. Cell Res. $173,322-340$.

11. Li, M. L., Aggeler, J., Farson, D. A., Hatier, C., Hassell, J., and Bissell, M. J. (1987) Proc. Natl. Acad. Sci. USA 84, 136-140.

12. Guyette, W. A., Matusik, R. J., and Rosen, J. M. (1979) Cell 17, 1013-1023.

13. Chirgwin, J., Przbyla, A., MacDonald, R., and Mutter, W. (1979) Biochemistry 18, 5294-5298.

14. Maniatis, T., Fritsch, E. F., and Sanbrook, J. (1982) in Molecular Cloning: A Laboratory Manual, Cold Spring Harbor Laboratory, Cold Spring Harbor, NY.

15. Richards, D. A., Blackburn, D. E., and Rosen, J. M. (1981) J. Biol. Chem. 256, 533-538.

16. Dugaiczyk, A., Haron, J. A., Stone, E. M., Dennison, D. F., Rothblum, K. N., and Schwartz, R. J. (1983) Biochemistry 23, 1605-1613.

17. Gunning, P., Ponte, P., Okayama, H., Engell, J., Blau, H., and Kedes, L. (1983) Mol. Cell. Biol. 3, 787-795.

18. Sood, A. K., Pereira, D., and Weissman, S. M. (1981) Proc. Natl. Acad. Sci. 78, 616-620.

19. Kafatos, F. C., Jones, C. W., and Efstratiadis, A. (1979) Nucleic Acids Res. 7, 1541-1547.

20. Amersham Technical Bulletin (1984) Procedures for Liquid Scintillation Counting of Filters.

21. Jacobson, A. (1987) in Methods in Enzymology (Grossman, L. I., and Moldave, K., Eds.), Vol. 152, pp. 254-261, Academic Press, New York.

22. Harris, S. E., Rosen, J. M., Means, A. R., and O'Malley, B. W. (1975) Biochemistry 14, 2072-2081.

23. Palmiter, R. D. (1973) J. Biof Chem. 248, 8260-8270.

24. Rogers, J. R., Johnson, M. L., and Rosen, J. M. (1985) in Methods in Enzymology (Grossman, L. I., and Moldave, K., Eds.), Vol. 109, pp. 572-592, Academic Press, New York.

25. Thompson, C. B., Challoner, P. B., Neiman, P. E., and Groudine, M. (1986) Nature $319,374-380$.

26. Teyssot, B., and Houdebine, L. M. (1980) Eur. J. Biochem. 110, 263-272.

27. Shiu, R. P., and Friesen, H. G. (1980) Annu. Rev. Physiol. 42, 83-96.

28. Taketani, Y., and Oka, T. (1986) Horm. Metab. Res. 18, 119-25.

29. Kafatos, F. C. (1972) in Gene Transcription in Reproductive Tissue (Diczfalusy, E., Ed.), Vol. 5, pp. 319-345, Karolinska Symposia on Research Methods in Reproductive Endocrinology.

30. Ocalan, M., Goodman, S. L., Kuhl, U., Hauschka, S. D., and VonderMark, K. (1988) Dev. Biol. 125, 158-167.

31. Panayotou, G., End, P., Aumailley, M., Timpl, R., and Engel, J. (1989) Cell 56, 93-101.

32. Goodman, S. L., Dentzmann, R., and Von der Mark, K. (1987) J. Cell Biol. 105, 589-598.

33. Terranova, P., Aumailley, M., Sultan, L. H., Martin, G. R., and Kleinman, H. K. (1986) J. Cell. Physiol. 127, 473-479.

34. Goodman, S. L., Risse, G., and Von der Mark, K. (1989) J. Cell Biol. 109, 799-809.

35. Grant, D. S., Tashiro, K., Segui-Real, B., Yamada, Y., Martin, G. R., and Kleinman, H. K. (1989) Cell 58, 933-943.

36. Kuhl, U., Ocalan, M., Timpl, R., and Von der Mark, K. (1985) Dev. Biol. 117, 628-635. 
37. Eisenstein, R. S., and Rosen, J. M. (1988) Mol. Cell. Biol. 8, 3183-3190.

38. Goodman, H. S., and Rosen, J. M. (1990) Mol. Endocrinol. 4, 1661-1670.

39. Bagchi, T., Larson, D. E., and Sells, B. H. (1987) Exp. Cell Res. 168, 160-172.

40. Bonneau, A., Darveau, A., and Sonenberg, N. (1985) J. Cell Biol. 100, 1209-1218.

11. Cervera, M., Dreyfuss, G., and Penman, S. (1981) Cell 23, 113120.

42. Ornelles, D. A., Fey, E. G., and Penman, S. (1986) Mol. Cell. Biol. 6, 1650-1662.

43. Brown, S. W., Malinoff, H. L., and Wicha, M. S. (1983) Proc. Natl. Acad. Sci. USA 80, 5927-5930.

44. Cody, R. L., and Wicha, M. S. (1986) Exp. Cell Res. 165, 107116.

45. Malinoff, H. L., and Wicha, M. S. (1983) J. Cell Biol. 96, 14751479.

46. Rao, N. C., Barsky, G. H., Terranova, V. P., and Liotta, L. A. (1983) Biochem. Biophys. Res. Commun. 111, 804-808.

47. Yannariello-Brown, J., Wewer, U., Liotta, L., and Madri, J. A. (1988) J. Cell Biol. 106, 1773-1786.

48. Sugrue, S. P., and Hay, E. D. (1981) J. Cell Biol. 91, 4554-4561.

49. Tamkun, J. W., DeSimone, D. W., Fonda, D., Patel, R. S., Buck, C., Horwitz, J., and Hynes, R. O. (1986) Cell 46, 271-282.
50. David, G., and Bernfield, M. (1981) J. Cell Biol. 91, 281-286.

51. Emerman, J. T., and Pitelka, D. R. (1977) In Vitro 13, 316-327.

52. Martinez-Hernandez, A. L., Fink, M., and Pierce, G. B. (1976) Lab. Invest. 34, 455-462.

53. Parry, G., Lee, E. Y. H., Farson, D., Koval, D., and Bissell, M. J. (1985) Exp. Cell Res. 156, 487-499.

54. Wicha, M. S., Liotta, L. A., Vonderhaar, B. K., and Kidwell, W. R. (1980) Dev. Biol. 80, 253-266.

55. Timpl, R., Rohde, H., Robey, P. G., Rennard, S. 1., Foidart, J., and Martin, G. R. (1979) J. Biol. Chem. 254, 9933-9939.

56. Doppler, W., Groner, B., and Ball, R. K. (1989) Proc. Natl. Acad. Sci. USA 86, 104-108.

57. Doppler, W., Hock, W., Hofer, P., Groner, B., and Ball, R. K. (1990) Mol. Endocrinol. 4, 912-919.

58. Yoshimura, M., and Oka, T. (1990) Proc. Natl. Acad. Sci. USA 87, 3670-3674.

59. Schmidhauser, C., Bissell, M. J., Myers, C. A., and Casperson, G. F. (1990) Proc. Natl. Acad. Sci. USA 87, 9118-9122.

60. Scmitt-Ney, M., Soppler, W., Ball, R. K., and Groner, B. (1991) Mol. Cell. Biol. 11, 3745-3755.

61. Ben-Ze'ev, A., Robinson, G. S., Bucher, N. L., and Farmer, S. R. (1988) Proc. Natl. Acad. Sci. USA 85, 2161-2165.

62. Greenberg, M. E., and Ziff, E. B. (1984) Nature 311, 433-437.

63. Rapraeger, A., Jalkanen, M., and Bernfield, M. (1986) J. Cell Biol. 103, 2683-2696. 